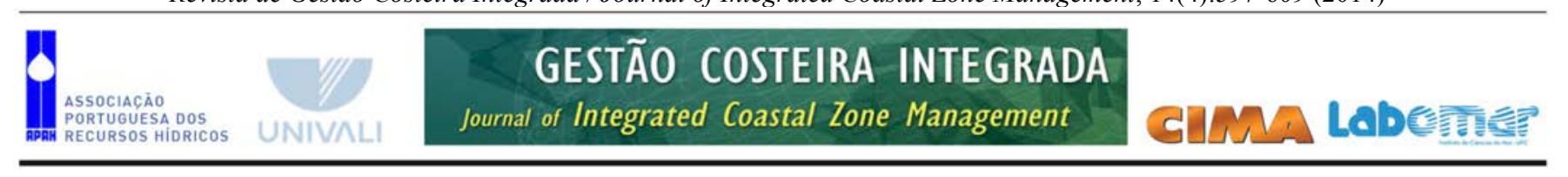

http://www.aprh.pt/rgci/pdf/rgci-506_Moreira-Gonzalez.pdf

DOI:10.5894/rgci506

\title{
Spatial and temporal distribution of phytoplankton as indicator of eutrophication status in the Cienfuegos Bay, Cuba
}

\author{
Angel Moreira-González ${ }^{@, ~ a ; ~ M a b e l ~ S e i s d e d o-L o s a ~}{ }^{\mathrm{a}}$; \\ Alain Muñoz-Caravaca ${ }^{\text {; }}$ Augusto Comas-González ; Carlos Alonso-Hernández ${ }^{a}$
}

\begin{abstract}
An important consequence of eutrophication is the increased prevalence of harmful algal blooms that affect transitional and coastal waters, and ecosystems in open seas. In this work, data on phytoplankton biomass, presence of harmful/toxic algal blooms and bottom dissolved oxygen were analyzed as indicators of overall eutrophic condition in the Cienfuegos Bay, Cuba. Samples were collected every three months during the year 2009 at fifteen representative stations within the bay. In the dry and early rainy seasons, high chlorophyll $a$ values, harmful/toxic dinoflagellate blooms and fish mortality episodes were encountered within riverine-urban wastewater discharge zones, whilst most part of the bay did not evidence symptoms of eutrophication. During the rainy season, some stations showed biological stress-hypoxia for the bottom water oxygen, and a strong increase in spatial dispersion was observed in the phytoplankton biomass, due to a substantial increment in not toxic diatom abundance, resulting in a moderate level of eutrophic conditions for chlorophyll $a$ in the entire bay. The key factor that supports the seasonal variation in phytoplankton composition and abundance appears to be the water residence time inside the bay.
\end{abstract}

Keywords: Cienfuegos Bay, chlorophyll $a$, ecological quality, eutrophication, harmful algal blooms

\section{RESUMO}

Distribuição espacial e sazonal do fitoplâncton como indicador do estado de eutrofização na Baía de Cienfuegos, Cuba

Uma importante consequência da eutrofização é o incremento e persistência das florações algais nocivas que afetam as águas de transição e costeiras, e ecossistemas em mar aberto. Neste trabalho, dados sobre a biomassa do fitoplâncton, presença de florações algais nocivas/tóxicas e oxigénio dissolvido no fundo foram analisados como indicadores da condição eutrófica geral na Baía de Cienfuegos, Cuba. Foram recolhidas amostras a cada três meses durante o ano de 2009 em quinze locais representativas dentro da baía. Nas estações da seca e do começo do período chuvoso, altos valores de clorofila a, florações algais nocivas/tóxicas e episódios de mortandades de peixes foram encontrados dentro de zonas de descargas de rios e de resíduos urbanos, enquanto a maior parte da baía não evidenciou sintomas de eutrofização. Durante o periodo chuvoso, alguns locais mostraram estresse biológico-hypoxia para o oxigénio dissolvido no fundo e um forte incremento na dispersão espacial foi observado na biomassa do fitoplâncton devido a um incremento substancial na abundancia de diatomáceas não tóxicas, resultando num nível moderado de eutrofização para a clorofila a em toda a baía. O fator chave que suporta a variação sazonal na composição e abundância do fitoplâncton parece ser o tempo de residência da água dentro da baía.

Palavras-chave: Baía de Cienfuegos, clorofila a, eutrofização, florações algais nocivas, qualidade ecológica

\footnotetext{
@ Corresponding author to whom correspondence should be addressed: <angel@gestion.ceac.cu>

${ }^{a}$ Centro de Estudios Ambientales de Cienfuegos (CEAC), Ministerio de Ciencia, Tecnología y Medio Ambiente (CITMA), Carretera a Castillo de Jagua, Km 11/2, AP. 5, CP. 59350, Cienfuegos, Cuba.
}

* Submission: 21 APR 2014; Peer review: 27 MAY 2014; Revised: 18 JUN 2014; Accepted: 6 AUG 2014; Available on-line: 25 SEP 2014 


\section{Introduction}

Vulnerability of coastal and estuarine systems to natural and anthropic forcings is increasing as a consequence of direct and indirect human interventions in these environments. Coastal erosion and consequent shoreline retreat, inlet migration, infilling of estuaries and lagoons, and water quality problems, are often linked to coastal morphodynamic processes, and have highly significant socioeconomic impacts. If systems' resilience is surpassed, serious environmental and human losses may occur. Moreover, in several coastal stretches, sustainable exploitability limits have already been exceeded resulting from human-induced alterations. Collapse of some fishing activities due to changes in the bottom sediment distribution patterns, the reduction of nursery areas, and the loss of seaside resort areas, are some examples of these changes (Dias et al., 2011).

Nutrient enrichment of both land and water is a result of increased human population growth and many associated activities for food and energy production, and discharge of associated sewage and waste. The final result of nutrient loading to inland and coastal waters is often an increase in algal biomass, frequently dominated by one or more species or species groups; this process is called eutrophication (GEOHAB, 2006). In general, the primary producer changes, which may in part results from perturbations of natural ratios of nutrient elements, include shifts from diatoms to cyanobacteria or flagellates. Such degradation includes: aesthetic effects such as the appearance of red tides or excessive foam; decreases in water transparency resulting from greater biomass of phytoplankton; and decreases in bottom water or sediment pore-water oxygen content because of the decay of increased primary production (Bricker et al., 2003; Ferreira et al., 2007; Glibert et al., 2005).

In many cases, the responding dominant species of phytoplankton are not toxic and, in fact, are beneficial to coastal productivity until they exceed the assimilative capacity of the system, after which hypoxia and other adverse effects occur (suffocation of fish, direct toxic effects on fish and shellfish, suffocation of fish from stimulation of gill mucus production, mechanical interference with filter feeding by fish and bivalve molluscs, and deleterious effects on submerged grasses and benthic habitat organisms). When that threshold is reached, seemingly harmless species can have negative impacts (Ferreira et al., 2011).

Many methods have been developed to evaluate and track trends in eutrophication in order to fulfil requirements of legislation designed to monitor and protect coastal water bodies from degradation. Most eutrophication assessment methods recognize that the immediate biological response is increased primary production reflected as increased chlorophyll $a$ and/or macroalgal abundance. These are direct effects or primary symptoms that indicate the first stages of eutrophication. Indirect effects or secondary symptoms such as low dissolved oxygen, losses of submerged aquatic vegetation, and occurrences of nuisance and/or toxic algal blooms are indicative of a more advanced phase of ecosystem degradation (Borja et al., 2008; Bricker et al., 2003, 2008; Ferreira et al., 2007; Xiao et al., 2007).

In general, harmful algal blooms cause significant ecological and economic damage, for example through impacts on wild life, fisheries, aquaculture, human health and tourism (GEOHAB, 2006). Management and mitigation strategies of these different problems are needed; monitoring activity (early detection of cells or toxins) is an essential element in order to take management actions. For example, it is useful to have flow charts or action plans outlining the steps to be taken in different circumstances, such as a human poisoning or fish mortality episode. The retentive nature of some semi-enclosed coastal systems, such as estuaries and fjords, can produce long residence times leading to prolonged suitable periods for harmful/toxic cells to thrive (Cembella et al., 2005).

The Cienfuegos Bay and its coastal line represent the most important natural resource in the Cienfuegos province, southern-central coast of Cuba due to fishing $(6 \%)$ and industrial activities (7\%), agriculture $(2 \%)$, maritime transport (7\%), natural parks $(70 \%)$, urbanization and tourism (8\%). Several rivers flow towards the bay, forming an estuarine system (Seisdedo \& Muñoz, 2005). Up to now, only a few biological studies have been carried out in the area, mainly concerning seaweeds, meio and macrobenthos and fishing resources (Aguilar et al., 1992; Armenteros et al., 2009; Helguera et al., 2011; Moreira et al., 2006). Although the composition of phytoplankton in the Cienfuegos Bay has been reported previously (Moreira et al., 2007), the analysis of chlorophyll $a$ concentrations as indicator of phytoplankton primary productivity (first stage of eutrophication) and nuisance and toxic algal blooms as secondary symptoms of water quality degradation remain unexplored. Recent observations on areas close to sewage from the Cienfuegos city have shown deterioration of benthic communities, large blooms of filamentous seaweeds, and dead fish coinciding with the occurrence of red tides. Also, the Cienfuegos Bay has been affected by the invasive species green mussel (Perna viridis), an edible filter-feeding bivalve, which can accumulate in their tissues contaminants (pesticides, heavy metals) and toxins from microalgae (Alonso-Hernández et al., 2012; Chang et al., 2004).

The main objective of this study is to describe the spatial and temporal distribution of phytoplankton compo- 
sition and biomass, with emphasis on harmful algal blooms and other parameters as indicators of the overall eutrophic condition in the Cienfuegos Bay, Cuba, during the year 2009. These indicators will provide adequate information to guide management decisions critical to mitigate harmful algal blooms in the Cienfuegos Bay.

\section{Material and methods}

\subsection{Study Area}

The Cienfuegos Bay, situated in the southern central part of Cuba, is a semi-enclosed bay with a surface area of $90 \mathrm{~km}^{2}$ and an average depth of $14 \mathrm{~m}$. It is connected to the Caribbean Sea by a narrow channel $3 \mathrm{~km}$ long. The bay is divided in two well-defined hydrographic basins due to the presence of a submerged ridge $1 \mathrm{~m}$ below the surface, just North of the connection channel (Fig. 1).

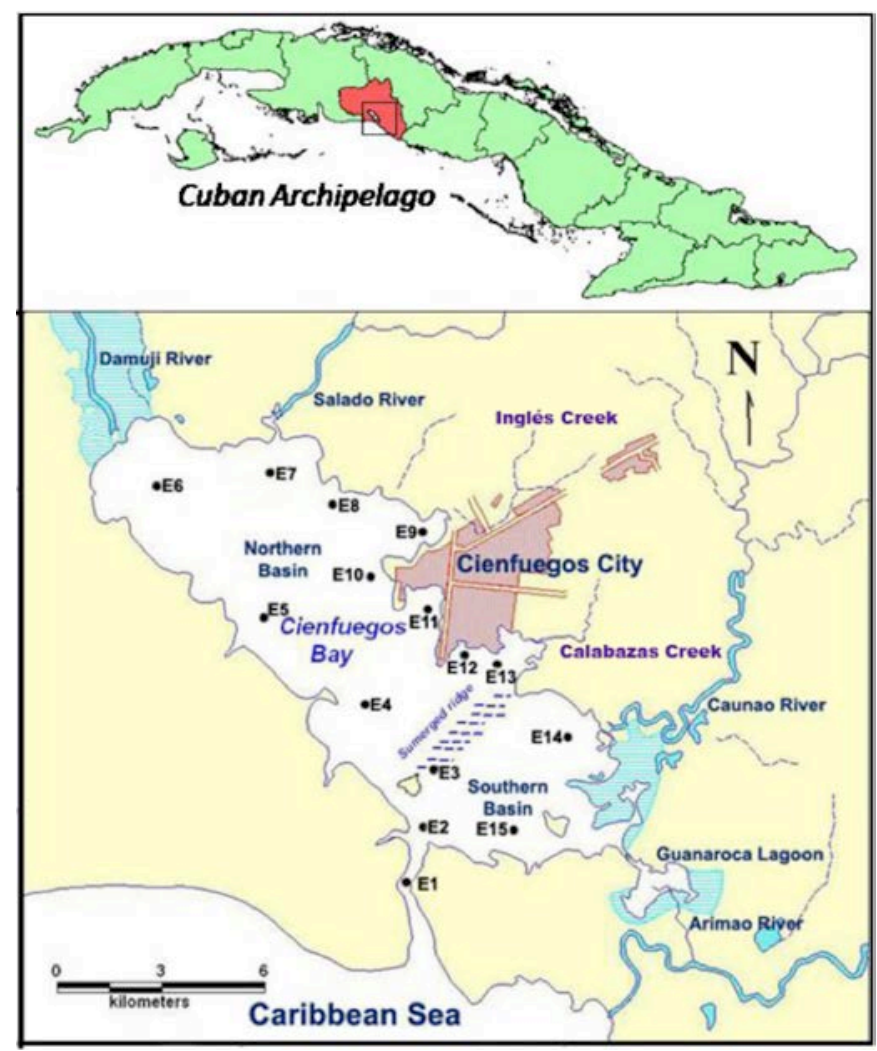

Figure 1 - Map of the Cienfuegos Bay showing the sampling stations.

Figura 1 - Mapa da Baía de Cienfuegos assinalando as estações de amostragem.

The northern basin receives most of the anthropic impact from the outfall of the Cienfuegos city (140 734 inhabitants), industrial pole in the country, the freshwater input of the Damuji and Salado rivers and other less extensive river basins such as El Inglés, Calabazas and Manacas creeks. In the region, the rate of population growth is low; and despite the introduction of actions by the government to reduce the pollution in the bay, the wastewater treatment is inadequate. The southern basin is subject to a smaller degree of anthropic pollution originated from the Caonao and Arimao rivers (Muñoz-Caravaca et al., 2012). The Guanaroca lagoon, located in the southern basin is a natural park, a niche for protected migratory birds and marine species.

Weather conditions in the study area can be divided in two seasons: dry (November - April) and rainy (May October) season. The annual mean temperature is $24.7^{\circ} \mathrm{C}$, the highest monthly temperature occurs in the rainy season, $27.0^{\circ} \mathrm{C}$ in June, and the lowest occurs in the dry season, $21.6^{\circ} \mathrm{C}$ in January. From a rainfalls time series $(1967$ - 2006) in Cienfuegos province, the annual accumulated rainfall was $1507.5 \mathrm{~mm} ; 81 \%$ of this accumulated fall in the rainy season and $19 \%$ in the dry season (Barcia et al., 2009). The bay has a marked vertical haline stratification caused by runoff from land and low tidal mixture. During the rainy season (May October) the mean values of surface salinity are low (16 - 20), but remain high at the bottom. During the dry season, salinity takes values between 30 and 32 throughout the water column (Seisdedo \& Muñoz, 2005).

\subsection{Water sampling and analyses}

In order to describe wet and dry conditions, throughout 2009 , four oceanographic cruises were carried out in April (dry), June (early rainy), September (rainy) and November (early dry). Samples were collected in the surface waters $(0-1 \mathrm{~m})$, at 15 fixed stations. The bay was surveyed, always, during high tide. The stations were selected taking into account the spatial variability and their locations in defined vulnerable areas: incidence of freshwater discharges (E6-7, E14-15), industrial and urban activity (E8-13). Water samples were collected with a Niskin bottle for temperature, salinity, dissolved oxygen, chlorophyll $a$, nitrite, nitrate, ammonium and phosphate analysis.

At each station, subsurface-water temperature and salinity were sampled with a multisonde YSI-30. Nitrite, nitrate and ammonium were measured following the technique proposed in Grasshoff (1999). The concentration of dissolved inorganic nitrogen (DIN) was calculated as the sum of the ammonium, nitrate and nitrite concentrations. Phosphate was measured using the method described in UNEP (1988). The concentration of bottom dissolved oxygen in seawater was determined using the Winkler method. Total chlorophyll $a$ concentration was measured by filtering sea water $(0.2-2.5 \mathrm{~L})$ through glass fiber filters (Whatman GF/F). Pigments were extracted in 10 $\mathrm{ml}$ of $90 \%$ acetone, for $48 \mathrm{~h}$, in dark and cold conditions. The absorbance of the extract was measured by spectrophotometric method following UNEP (1988). 
A $250 \mathrm{ml}$ subsurface-water sample was collected for phytoplankton community structure analysis and preserved with $2.5 \mathrm{ml}$ of neutral Lugol' iodine solution. For quantitative analysis, samples were settled using sedimentation chambers of $25 \mathrm{ml}$, and phytoplankton cells were counted in an inverted microscope Zeiss (Axiovert 40) (Utermöhl, 1958). For taxonomic purposes, water samples were concentrated with a $20 \mu \mathrm{m}$ phytoplankton net and were fixed with neutral Lugol' iodine solution. Algal taxa were identified almost always to species using a number of taxonomic texts (Hallegraeff et al., 2003; Tomas, 1997).

\subsection{Water data analysis}

For each parameter (dissolved nutrients, DIN/DIP ratios, bottom dissolved oxygen and chlorophyll $a$ ), whenever statistical analysis was conducted for one variable (campaign or month) with 15 groups (sampling stations), the exploratory analysis was followed by a Mann-Whitney test (when data did not obey normality and homoscedastic assumptions) (Zar, 2009). The relationship between chlorophyll $a$ and nutrient concentrations was established by Spearman's correlation coefficient. SPSS software (IBM SPSS Statistics V15) was used for the statistics methodology, with a 0.05 value of significance. The geographic information system (GvSIG.1.10) was used to create maps of salinity, chlorophyll $a$ and bottom dissolved oxygen.

\subsection{Overall Eutrophic Condition}

Some parameters of ASSETS (Assessment of Estuarine Trophic Status) methodology (Bricker et al., 2003) such as chlorophyll $a$, bottom dissolved oxygen and harmful/toxic algal blooms were applied comparatively to rank the eutrophication status of the Bay. Excessive concentration of chlorophyll $a$ is a primary symptom of eutrophication; the thresholds and ranges $(\mu \mathrm{g} / \mathrm{L})$ used were: Hypereutrophic $>60$; High 20-60; Moderate 5-20; Low $0-5$. The occurrence of nuisance/toxic algal blooms and low dissolved oxygen are secondary symptoms or indicators of well-developed problems with eutrophication. The thresholds and ranges $(\mathrm{mg} / \mathrm{L})$ for dissolved oxygen were: Anoxia: 0; Hypoxia 0-2; Biologically stressful 2-5.

\section{Results and discussion}

\subsection{Physic-chemical conditions}

Mean values of sea surface water temperature ranged between $26.3{ }^{\circ} \mathrm{C}$ in dry and $30.2{ }^{\circ} \mathrm{C}$ in rainy, and salinity from 30.3 in rainy to 34.9 in dry season. During the studied sampling period, mean values of salinity were never below 25 , thus the entire system should be classified as a Seawater Zone (Fig. 2), based on the National Estuarine Inventory classification (NEI; NOAA, 1985).

Mean values of dissolved inorganic nutrient concentrations, DIN/DIP ratios, bottom dissolved oxygen and chlorophyll $a$ concentration during 2009 campaigns are listed in Table 1.

The concentrations of DIN and DIP were highest in early rainy and early dry seasons, respectively. The mean values of DIN:DIP $(<16)$ ratios showed that nitrogen was the limiting nutrient. This molar ratio did not change significantly from dry to early rainy season (maximum value) $(\mathrm{p}>0.05)$, contrary to the following periods from early rainy to rainy season and from rainy to early dry season. Although the nutrient concentrations were moderate in general, the higher peaks of nitrogen and DIN/DIP ratios in areas close to sources of pollution during dry and early rainy seasons could induce algal blooms during these seasons in the Cienfuegos Bay. Altered nutrient ratios have been

Table 1 - Values of dissolved nutrients, chlorophyll $a$, bottom dissolved oxygen and DIN/DIP ratio during 2009 campaigns.

Tabela 1 - Valores dos nutrientes dissolvidos, clorofila a, oxigênio dissolvido no fundo e a relação NID/PID durantes os monitoramentos de 2009.

\begin{tabular}{cccccccccc}
\hline Parameters & \multicolumn{2}{c}{ April } & \multicolumn{2}{c}{ June } & \multicolumn{2}{c}{ September } & \multicolumn{2}{c}{ November } \\
& Mean & SD & Mean & SD & Mean & SD & Mean & SD \\
\hline DIN $(\mu \mathrm{mol} / \mathrm{L})$ & 2.97 & 3.76 & 3.46 & 1.72 & 2.79 & 2.19 & 1.21 & 0.99 \\
DIP $(\mu \mathrm{mol} / \mathrm{L})$ & $<0.52$ & - & $<0.52$ & - & 1.34 & 2.77 & 2.45 & 0.73 \\
DIN/DIP ratio & 5.75 & 7.28 & 6.70 & 3.33 & 3.56 & 3.27 & 0.55 & 0.60 \\
Chlorophyll $a(\mu \mathrm{g} / \mathrm{L})$ & 5.62 & 9.58 & 3.70 & 2.51 & 6.56 & 1.55 & 3.58 & 1.29 \\
Bottom Diss.O $\mathrm{O}_{2}(\mathrm{mg} / \mathrm{L})$ & 5.82 & 0.49 & 4.88 & 1.83 & 4.71 & 1.93 & 6.32 & 1.03 \\
\hline
\end{tabular}

DIN Dissolved Inorganic Nitrogen, DIP Dissolved Inorganic Phosphorous, SD Standard deviation. 


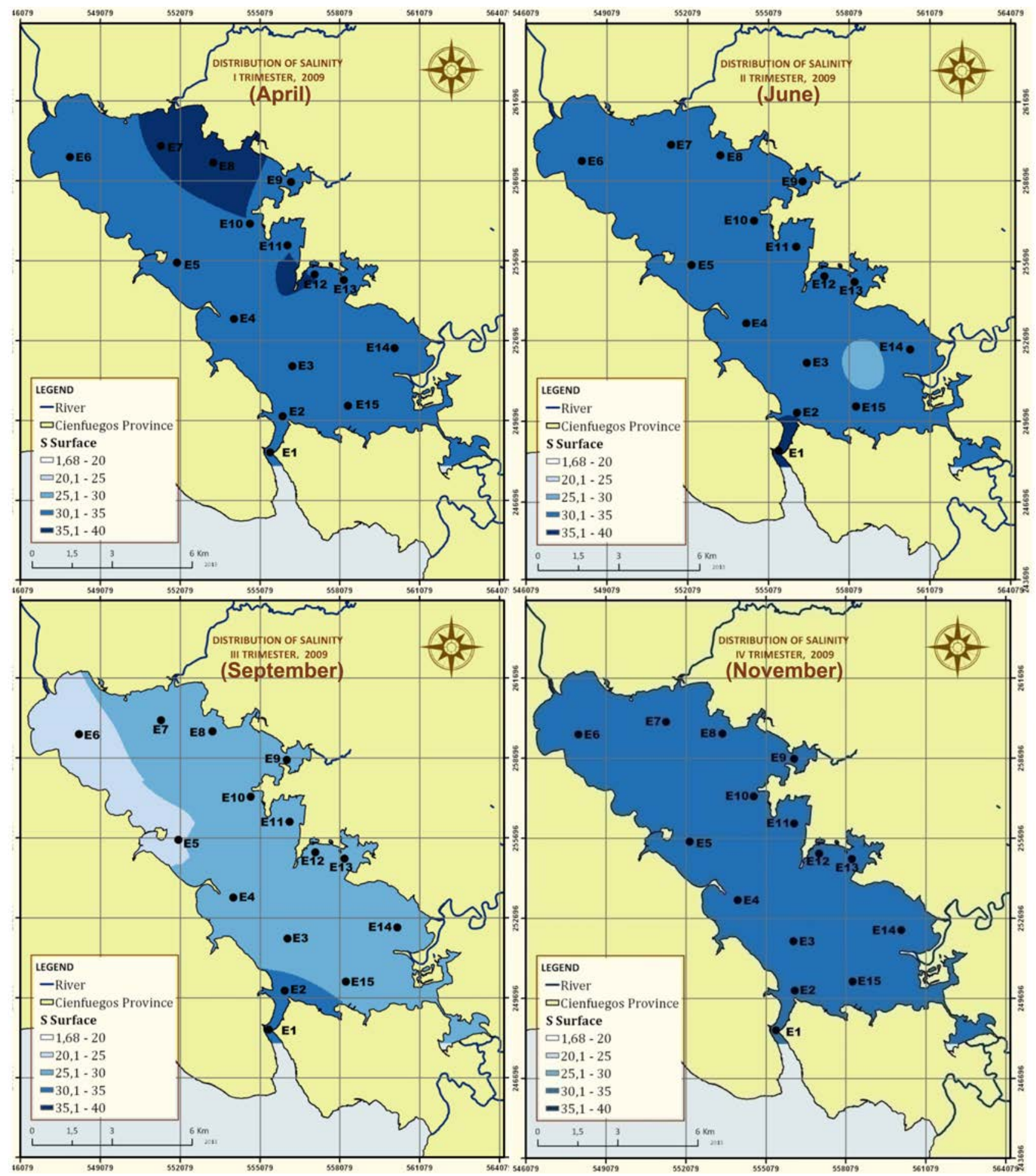

Figure 2 - Seasonal and spatial variation of surface salinity during the year 2009 in the Cienfuegos Bay, Cuba.

Figura 2 - Variação espacial e sazonal da salinidade da superfície durante o ano 2009 na Baía de Cienfuegos,

correlated with the increase of harmful algal blooms and shifts from diatom-dominated to flagellatedominated assemblages in coastal water worldwide (Glibert et al., 2005). From early rainy to rainy season, DIN values decreased, yet nitrate concentrations showed a significant increase $(p<0.05)$, which could be related to increased concentrations of chlorophyll $a$. In fact, we find significant positive Spearman correlations between chlorophyll $a$ and nitrate concentrations
(0.312). From rainy to early dry season, phosphate concentrations increased significantly $(p<0.05)$, which led to a decrease in the DIN:DIP ratios $(\mathrm{p}<0.05)$.

Although most of the bottom water oxygen values were within the range of 5 to $7 \mathrm{mg} / \mathrm{L}$, stations E4, E7, E8, E13 and E15 showed values below this threshold (Biological Stress), and particularly in stations E5 and E10 hypoxia values were observed during the early rainy and rainy seasons. (Fig. 3). 


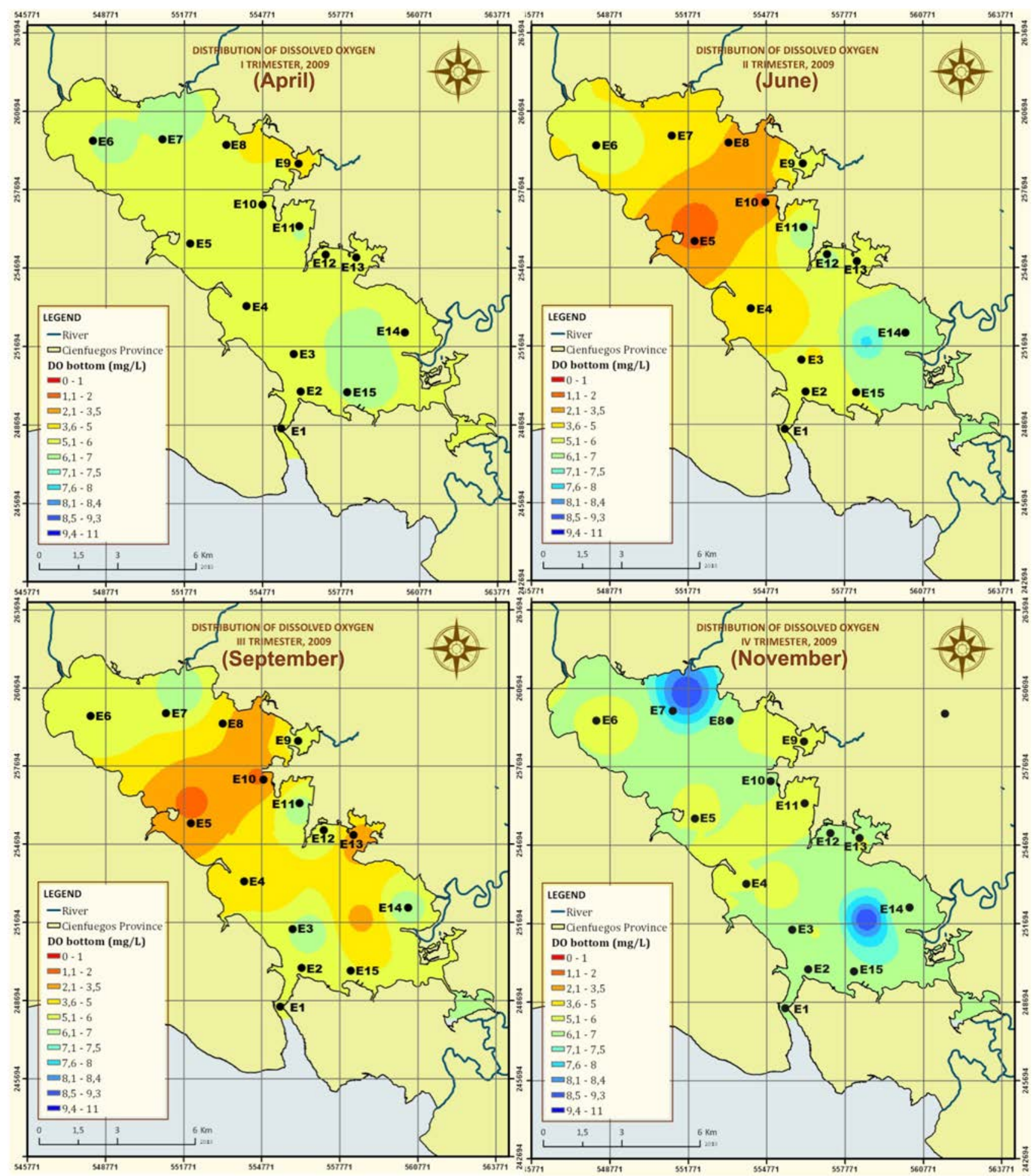

Figure 3 - Seasonal and spatial variation of bottom dissolved oxygen during the year 2009 in the Cienfuegos Bay, Cuba.

Figura 3 - Variação espacial e sazonal do oxigênio dissolvido no fundo durante o ano 2009 na Baía de Cienfuegos, Cuba.

The concentrations of dissolved oxygen at bottom waters showed statistically significant differences $(\mathrm{p}<0.05)$ between rainy and early dry seasons when hypoxic conditions disappeared in some areas. The low concentrations of oxygen at bottom waters observed during the rainy season could be caused by the stratification and removal of sediments due to runoff from land (Seisdedo \& Muñoz, 2005). Also, it could reflect the natural and anthropogenic pressures that the Cienfuegos Bay has suffered. According to Helguera et al. (2011), high organic enrichment and heavy metal concentrations in sediments have been reported in this semi-enclosed bay of low hydrodynamic regime and high sedimentation rates (Alonso-Hernández et al., 
2006). Also, the sink and decay of algal blooms contribute to eutrophication and oxygen depletion in bottom waters (Ferreira et al., 2011; Glibert et al., 2005). This environmental variable can be considered as dissolved oxygen saturation, which depends on both salinity and temperature (Millero, 2006). Thus, we also analyzed its values and obtained correspondence with the previous results. The lowest concentrations were obtained in stations E5 (17.8\%) and E10 (27.9\%) during the early rainy and rainy seasons, respectively.

\subsection{Chlorophyll $a$}

The highest concentrations of chlorophyll $a$ were registered during the dry season, only at three stations influenced by anthropogenic pressures: $9.95 \mu \mathrm{g} / \mathrm{L}$ (station E7), $11.85 \mu \mathrm{g} / \mathrm{L}$ (station E9) and $38.17 \mu \mathrm{g} / \mathrm{L}$ (station E8). With the exception of these peaks, the values of chlorophyll $a$ observed at the other stations during the dry season were relatively low (average of $5.62 \mu \mathrm{g} / \mathrm{L})$. The highest average concentrations $(6.56 \mu \mathrm{g} / \mathrm{L})$ of chlorophyll $a$ were found in the rainy season (Fig. 4).

According to the ASSETS thresholds, the maximum values of chlorophyll $a$ obtained for the dry season (stations E7, E8 and E9) fall within the High and Moderate level of eutrophic conditions, while the values observed during rainy season are classified as Moderate. Most values observed in early rainy (average of $3.70 \mu \mathrm{g} / \mathrm{L}$ ) and early dry seasons (average of $3.58 \mu \mathrm{g} /$ L) were always lower than the thresholds of $5 \mu \mathrm{g} / \mathrm{L}$, which classifies these periods in the Low category of eutrophic conditions (Fig. 4).

Dinoflagellate blooms were associated with the highest values of chlorophyll $a$, although hypoxia symptoms were not observed. The key factors supporting the high concentration of chlorophyll $a$ near areas of sewage and riverine discharges (around the Cienfuegos city, E7-9) in the dry season appear to be the availability of nutrients, both inorganic and organic, in these enclosed areas; and the long residence time of the system during the dry season. The higher dissolved inorganic nitrogen and DIN/DIP ratios reported in the area of higher chlorophyll $a$, could be the result of nitrogen loading from the Salado River and El Inglés creek, which deliver over $50 \%$ of nitrogen and phosphorous present in the Cienfuegos Bay (Seisdedo \& Arencibia, 2010). In this context, natural resource managers in the bay should include action plans to reduce riverine inputs of nitrogen, with the aim to mitigate harmful algal bloom since the growth of phytoplankton in this area is limited primarily by nitrogen.

Recent studies have reported that the Cienfuegos Bay system has a slow exchange rate, with an average residence time of 39 days during the rainy period and 50 days during the dry one (Muñoz-Caravaca et al., 2012). Organic nutrients have been shown to be important in the development of blooms of various harmful algal species, in particular cyanobacteria and dinoflagellates (Glibert et al., 2001); and long water residence times in enclosed seas lead to blooms triggered to a large degree by internal and external nutrient pools (Ferreira et al., 2011). However, the spatial coverage for high concentrations of chlorophyll $a$ was low (only for three stations close to sewage and riverine discharges), indicating that the Cienfuegos Bay seems to have a high capacity to dilute nutrients.

The high chlorophyll $a$ concentration observed near areas of sewage during the dry season in Cienfuegos Bay has been recorded in other small semi-enclosed bays from Cuba. High densities of phytoplankton (1.02 $\mathrm{x} 10^{7} \mathrm{cells} / \mathrm{L}$ ) and chlorophyll $a$ concentrations $(25.2 \mathrm{ug} / \mathrm{L})$ have been observed in the Havana Bay. Eutrophic conditions in this bay were related to increased sewage discharges from Havana city (Reyes, 2008). More recently, during the dry season of 2012 (March), high chlorophyll $a$ concentration due to a bloom of Phaeocystis sp. has been observed for the first time in the Cuban archipelago, in Cayo Largo; a small island located in the south-western platform of Cuba. This site represents a highly hydrodynamic system. A red-brown bloom persisted for the next 15 days, affecting the tourism in the area because of the presence of abundant foam, water discoloration and bad odours. High concentrations of ammonium and organic nitrogen were subsequently recorded along the beaches. The high content of organic nitrogen relative to phosphorus suggests an excess of nitrogen during bloom conditions (Loza et al., 2013).

The progressive and spatially uniform increase in the chlorophyll $a$ observed from early rainy to rainy seasons in the Cienfuegos Bay can be explained in response to delivery of nutrients from rainfall events (GEOHAB, 2006). During the present study, the rainfall period was moderate and below the average historical flows (Seisdedo \& Muñoz, 2005). This environmental conditions favour the dominance of chain-forming and large marine diatoms which achieve moderate chlorophyll $a$ concentrations (Smayda, 1997), relative to the values observed during the dry season.

\subsection{Phytoplankton composition and abundance}

The taxonomic composition of phytoplankton communities and the mean values of cell abundance are listed in Table 2. A total of 94 species were identified during the study: 44 Dinoflagellates, 36 Diatoms, 9, Cyanophyceans, 3 Chlorophyceans, 1 Cryptophycean, 1 Chrysophycean, 1 Raphidophycean and 1 Prasinophycean. During the dry season, the community was dominated by diatoms, with relatively low abundances and species richness (Fig. 5 and Anexo I [at Supporting Information]). 


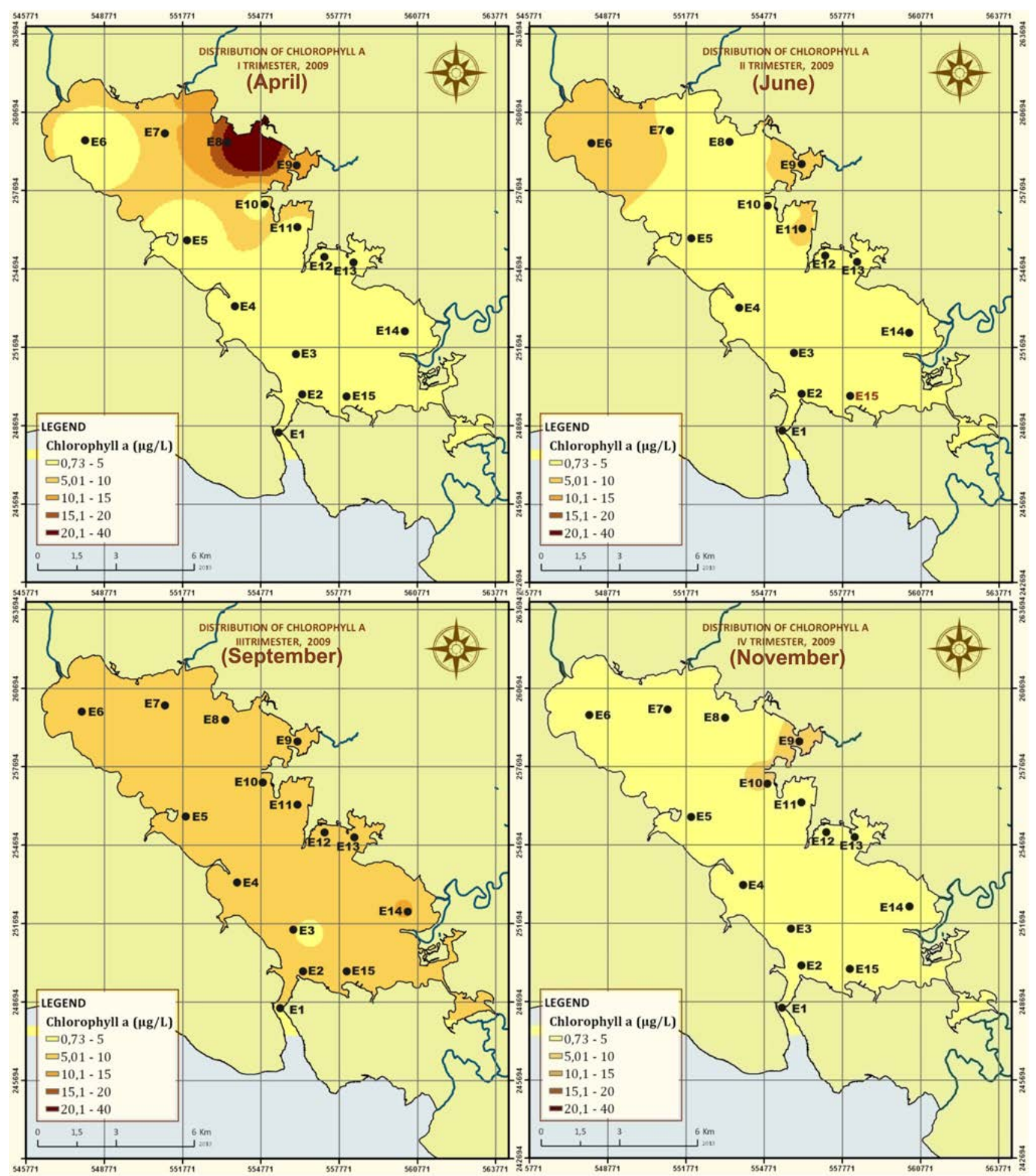

Figure 4 - Seasonal and spatial variation of chlorophyll $a$ during the year 2009 in the Cienfuegos Bay, Cuba.

Figura 4 - Variação espacial e sazonal da clorofila a durante o ano 2009 na Baía de Cienfuegos, Cuba. 

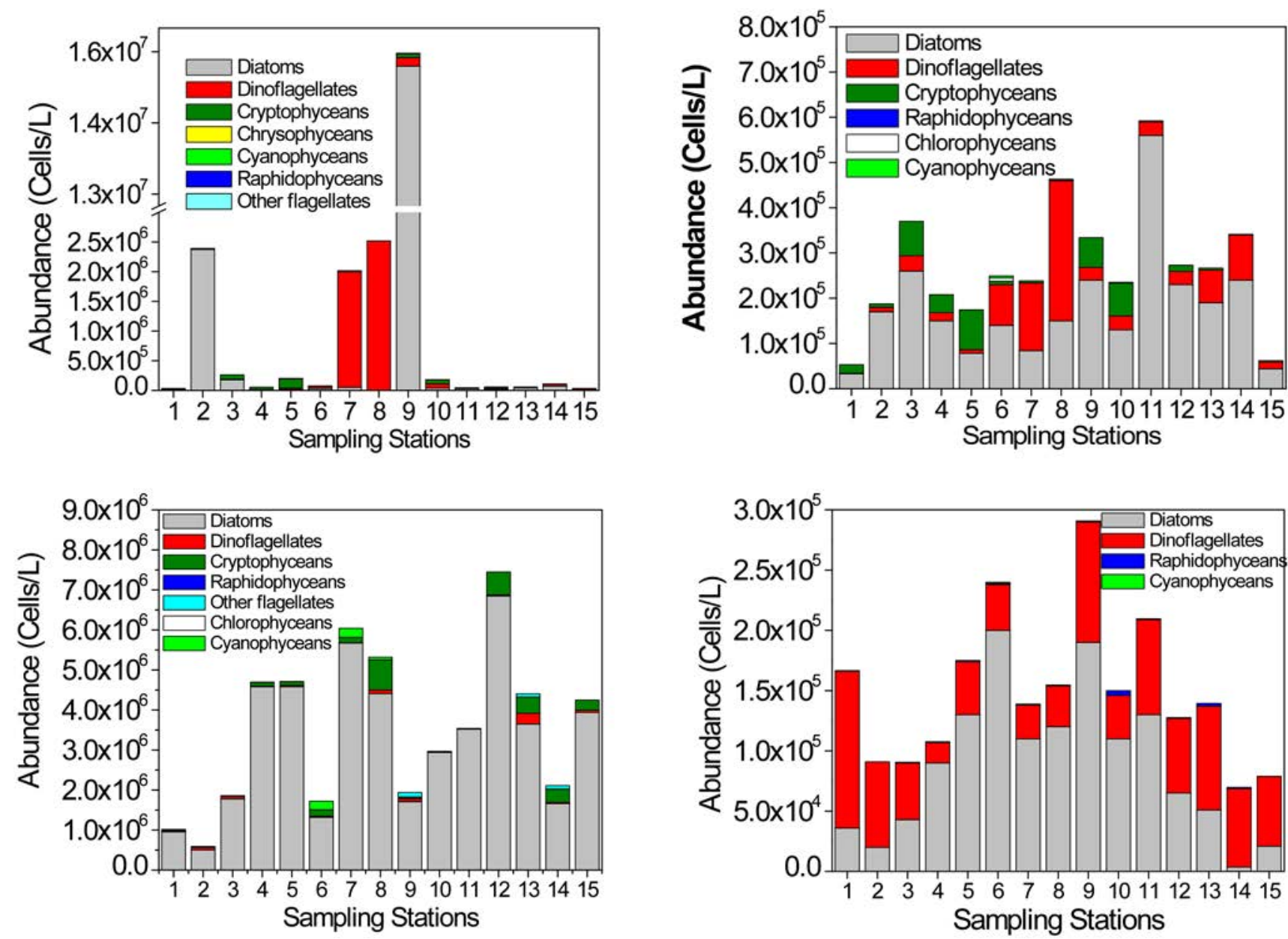

Figure 5 - Seasonal and spatial variation of the abundance (cells/L) of the main phytoplankton groups during the year 2009 in the Cienfuegos Bay, Cuba.

Figura 5 - Variação espacial e sazonal da abundancia (céls./L) dos principais grupos do fitoplâncton durante o ano 2009 na Baía de Cienfuegos, Cuba

The community was composed mainly of chainforming species of the genus Pseudo-nitzschia. However, high abundance of phytoplankton at stations E7, E8 and E9, during the dry season, was related to enhanced growth of dinoflagellates and diatoms, resulting in discoloured water. Blooms of the non toxic dinoflagellate Gymnodinium estuariale was observed in stations E7 and E8; while a mixed species assemblage of diatoms was observed at station E9, dominated by the species Cyclotella sp., Nitzschia longissima and the potentially toxic Pseudo-nitzschia multistriata (amnesic shellfish poisoning producing). No problems with oxygen depletion and marine life due to excessive growth of microalgae were observed at these stations. Large blooms of the filamentous brown seaweed Feldmannia irregularis were observed in shallow areas near the city (stations E8-13) during April and May coincident with the occurrence of microalgal blooms.

These blooms of macrophytes were shading the seagrass Halodule wrightii and in some beaches were the most likely responsible for bad odours due to their decomposition/degradation. These results give an overall rating of Moderate for Harmful and Toxic Algal Blooms at the stations near the Cienfuegos city (stations E8-13) in the dry season.

During the early rainy season, the abundance and diversity of large marine diatoms increased, due to the presence of several species of Chaetoceros, Cerataulina pelagica, Coscinodiscus centralis, Cyclotella sp., Dactyliosolen fragilissimus, Guinardia striata, Nitzschia longissima, Pseudoguinardia recta, Pseudonitzschia multistriata, Rhizosolenia hebetata f. semispina, Thalassionema nitzschioides and Thalassiosira sp. Dinoflagellates were only occasionally important; for example, at the E6, E7, E8 and E14 stations, dominated by the species Akashiwo sanguinea, Gymnodinium estuariale and Prorocentrum micans (Fig. 5 and Table 2). High abundance and richness of phytoplankton species associated with freshwater runoff is generally found in other studies from coastal lagoons in the Caribbean region (Álvarez-Góngora \& HerreraSilveira, 2006; Troccoli et al., 2004). 
However, in a shallow area outside of the monitoring network close to the station E11 and sewage effluents a red tide of the toxic dinoflagellate Heterocapsa circularisquama was recorded which was associated to a small episode of fish kill. Other potentially toxic or red tide dinoflagellates were observed in this area (Fig. 6), such as Akashiwo sanguinea (red tide producing); Alexandrium cf. minutum and Gymnodinium catenatum (paralytic shellfish poisoning producing); Dinophysis caudata, D. ovum and D. tripos (diarrhetic shellfish poisoning producing); Amphidinium carterae, Cochlodinium polykrikoides, Gonyaulax polygramma and $G$. spinifera (icthiotoxic compounds producing); Prorocentrum minimum (neurotoxic compounds producing) and $P$. rathymum, potentially producer of hemolytic compounds which could be associated to the ciguatera due to its benthic life.

Blooms of other non toxic dinoflagellates were also observed during this period in shallow near shore areas: Peridinium quinquecorne near station E11, Prorocentrum compressum near station E9 and Scrippsiella trocoidea near station E14. Due to the association of toxic red tides (H. circula-risquama) with fish kills an overall rating of Bad for Nuisance and Toxic Algal Blooms is attributed to the station E11 during the early rainy season. Several dinoflagellate genera, such as Prorocentrum, Phaeocystis, Heterocapsa, Scrippsiella, Cochlodinium, Heterosigma and others, have adaptations making them suitable for thriving in nutrientrich waters. Increasing evidence suggests that some of these species may also be increasing in their global extent (GEOHAB, 2006).
Cochlodinium polykrikoides and Heterocapsa cf. circularisquama blooms have been recently associated with the kill of many marine organisms (Crassostrea virginica = ostión, Callinectes sapidus = jaiba, Cetengraulis edentulus = bocón) in the Cienfuegos Bay, specifically within the protected area Guanaroca lagoon during the dry season (Moreira, unpublished data). This lagoon is located in the southern basin of the bay, which has more exchange with the Caribbean Sea. Previous reviews have supported that Cochlodinium is not a true " "eutrophic"' dinoflagellate (Kudela \& Gobler, 2012). These reports noted that both $C$. polykrikoides and $C$. fulvescens are capable of utilizing a variety of $\mathrm{N}$ compounds, but exhibit characteristics indicative of more pelagic rather than neritic/eutrophic dinoflagellates.

In the rainy season, a strong spatial gradient was observed in cell abundance, due to a substantial increment in diatoms' abundance. The peak during the rainy season was mainly caused by the diatom Dactyliosolen fragilissimus (average of $2.1 \times 10^{6}$ cells/L), followed by other species of diatoms as Rhizosolenia hebetata f. semispina, Cyclotella sp., Nitzschia longissima, Nitzschia sp., and cryptophytes of the genus Plagioselmis. The contribution of the dinoflagellates was very low (Figure 5 and Table 2). Freshwater species such as the diatom Aulacoseira granulata, the chloro-phytes Coenococcus sp., Coelastrum indicum, Desmodesmus abundans, and the potentially toxic cyano-bacteria Anabaena sp., Cylindrospermopsis curvispora, Microcystis aeruginosa, Oscillatoria sp., Phormidium sp., Planktothrix isothrix and Pseudo-
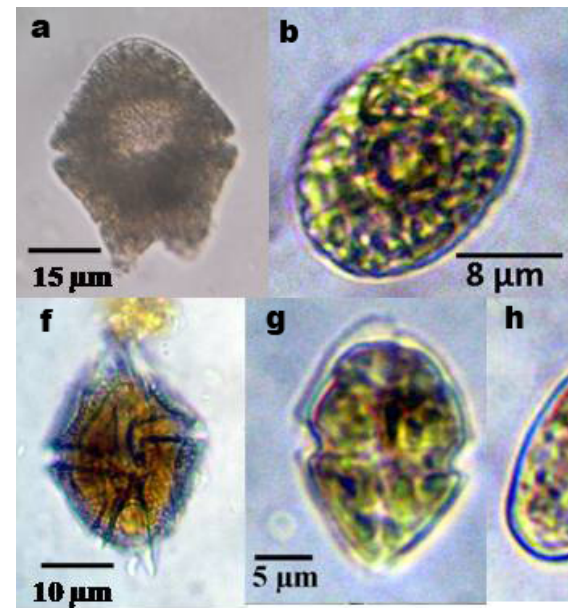

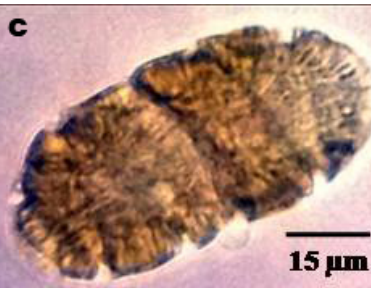

h

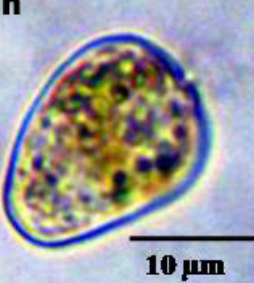

i

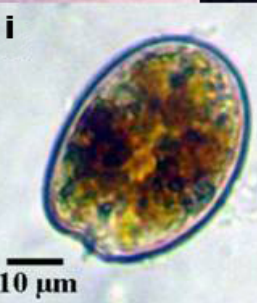

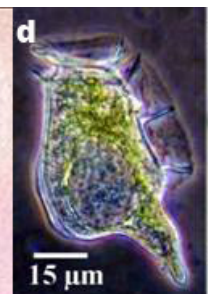

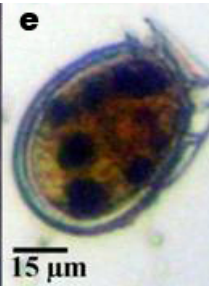

j

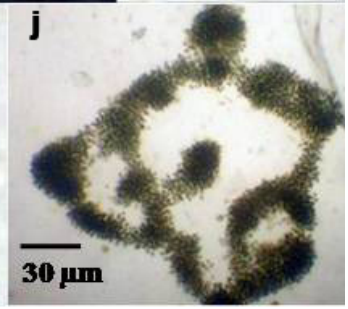

Figure 6 - Some potentially harmful/toxic marine and freshwater microalgae found during the year 2009 in the Cienfuegos Bay, Cuba. a. Akashiwo sanguinea. b. Amphidinium carterae. c. Cochlodinium polykrikoides.d. Dinophysis caudata. e. Dinophysis ovum. f. Gonyaulax polygramma. g. Heterocapsa circularisquama. h. Prorocentrum minimum. i. Prorocentrum rathymum. j. Microcystis aeruginosa (freshwater).

Figura 6 - Algumas microalgas potencialmente nocivas/tóxicas, marinhas e de água doce, encontradas durante o ano 2009 na Baía de Cienfuegos, Cuba. a. Akashiwo sanguinea. b. Amphidinium carterae. c. Cochlodinium polykrikoides. d. Dinophysis caudata. e. Dinophysis ovum. f. Gonyaulax polygramma. g. Heterocapsa circularisquama. h. Prorocentrum minimum. i. Prorocentrum rathymum. j. Microcystis aeruginosa (água doce). 
anabaena sp. were observed in low concentrations. These results are evidences that the phytoplankton species composition in an estuary can be linked to flushing time (Ferreira et al., 2005).

Dinoflagellates tend to be associated with slower flushing (dry season), reflecting both higher chlorophyll $a$ values and increased occurrence of harmful algal blooms, whilst diatoms depend on higher flushing and turbulence (rainy season), and the abundance of freshwater species in the estuary will represent an integrative measure of the phytoplankton community response to highest freshwater inflow.

Within the bay, during the early dry season, the abundance of dinoflagellates tended to increase and the contribution of diatoms was also important. The community was dominated by the diatom Thalassionema nitzschioides, together with the dinoflagellates Prorocentrum balticum, Prorocentrum micans and Protoperidinium steinii (Fig. 5 and Table 2). In the early dry season, phytoplankton abundance was lower compared with the rainy season. The overall composition of phytoplankton indicates that there are no problems with Harmful and Toxic Algal Blooms during the rainy and early dry seasons.

\section{Conclusions}

In summary, the Cienfuegos Bay is not particularly affected by problems associated with harmful algal bloom according to the Low-Moderate conditions diagnosed by two indexes, the concentration of Chlorophyll $a$ and the occurrence of harmful/toxic algal blooms. The level of expression for chlorophyll $a$ did not change significantly in the different scenarios, which is a consequence of the high dilution potential of the system, and the hydrodynamic limitations to bloom development in broad parts of the bay.

However, high levels of chlorophyll $a$, and the occurrence of harmful and toxic algal blooms were observed during the dry season in small enclosed areas with restricted water circulation/ renewal, and associated to direct discharges of urban/industrial effluents into the bay. The high water residence times found in the bay during the dry season is a factor within the estuary that contributes to maintain bloom conditions in these enclosed areas.

Management plans in the Cienfuegos Bay should be addressed to reduce sewage discharges into the receiving body. It will appear to be adequate for preserving and improving environmental quality as regards eutrophication and harmful algal blooms, principally in the waters of more restricted exchange of the bay.

The presence of harmful/toxic algal blooms during the dry period, suggests the need to continue monitoring the occurrence of these organisms, and to control the harvesting of molluscs during the periods of blooms, such as the edible bivalve green mussel (Perna viridis), which is an invasive species in the Cienfuegos Bay.

In order to mitigate the mortality of marine fauna (invertebrates and fishes) associated with the fishkilling dinoflagellate Cochlodinium polykrikoides, special attention should be focused on the study red tide events of this toxic microalga in the bay.

\section{Acknowledgments}

This work was supported by the IAEA Regional Project RLA-7-014 and the GEF-IWCAM Project (Integrating Watershed and Coastal Areas Management in Caribbean Small Island Developing States). We are very grateful to João Gomes Ferreira, from the IMAR, Portugal, for his valuable information on eutrophication in coastal and estuarine ecosystems; to Beatriz Reguera from IOC-IEO, Spain, for her important contribution about taxonomy and ecology on marine toxic microalgae; to the staff of Water Quality Laboratory from CEAC for its important contribution in the sampling and analytical assays and to Laura Castellanos for maps processing. We thank two anonymous reviewers for providing helpful comments and suggestions on the manuscript.

\section{References}

Aguilar, C.; González-Sansón, G.; Guevara, E.; Bosch, A. (1992) Estructura de las comunidades de peces en la Bahía de Cienfuegos y la Laguna Guanaroca, Cuba. Revista de Investigaciones Marinas (ISSN: 0252-1962), 13(3):222-232, Centro de Investigaciones Marinas, Universidad de La Habana, Habana, Cuba.

Alonso-Hernández, C.M; Díaz-Asencio, M.; Muñoz-Caravaca, A.; Delfanti, R.; Papucci,C.; Ferretti, O.; Crovato, C. (2006) Recent changes in sedimentation regime in Cienfuegos Bay, Cuba, as inferred from $210 \mathrm{~Pb}$ and $137 \mathrm{Cs}$ vertical profiles. Continental Shelf Research, 26(2):153-167. DOI: 10.1016/ j.csr.2005.08.026.

Alonso-Hernández, C.M; Gómez-Batista, M.; Cattini, C.; Villeneuve. J.P.; Oh, J. (2012) - Organochlorine pesticides in green mussel, Perna viridis, from the Cienfuegos Bay, Cuba.

Bulletin of Environmental Contamination and Toxicology, 89(5):995-999. DOI: 10.1007/s00128-012-0835-0.

Álvarez-Góngora, C.; Herrera-Silveira, J.A. (2006) - Variations of phytoplankton community structure related to water quality trends in a tropical karstic coastal zone. Marine Pollution Bulletin, 52(1):48-60. DOI: 10.1016/j.marpolbul.2005.08.006.

Armenteros, M.; Ruiz-Abierno, A.; Fernández-Garcés, R.; PérezGarcía, J.A.; Díaz-Asencio, L.; Vincx, M.; Decraemer, W. (2009) - Biodiversity patterns of free-living marine nematodes in a tropical bay: Cienfuegos, Caribbean Sea. Estuarine, Coastal and Shelf Science, 85(2):179-189. DOI: 10.1016/j.ecss. 2009.08.002.

Barcia, S.; Orbe, G.; Regueira, V.; Sánchez, R.; Núñez, E.; Rodríguez, C.; Hernández, A.L.; Angulo, R.; Ceballo, R.; Millán, J. (2009) - Guía Climática de la Provincia Cienfuegos. 
58p., Centro Meteorológico Provincial de Cienfuegos, INSMET, Cienfuegos, Cuba. Unpublished.

Borja, A.; Bricker, S.B.; Dauer, D.M.; Demetriades, N.T.; Ferreira, J.G.; Forbes, A.T.; Hutchings, P.; Jia, X.; Kenchington, R.; Marques, J.C.; Zhu, C.B. (2008) - Overview of integrative tools and methods in assessing ecological integrity in estuarine and coastal systems worldwide. Marine Pollution Bulletin, 56(9):1519-1537. DOI: 10.1016/j.marpolbul.2008.07.005.

Bricker, S.B.; Ferreira, J.G.; Simas, T. (2003) - An integrated methodology for assessment of estuarine trophic status. Ecological Modelling, 169(1):39-60. DOI: 10.1016/S03043800(03)00199-6.

Cembella, A.D.; Ibarra, D.A; Diogene, J; Dahl, E. (2005) - Harmful algal blooms and their assessment in fjords and coastal embayments. Oceanography, 18(2):158-171. DOI: 10.5670/oceanog. 2005.51.

Chang, I.; Rojas, L.; Franco, J.; La Barbera-Sánchez, A. (2006) Paralytic shellfish poisoning toxin profiles in green mussels from Trinidad and Venezuela. Journal of Food Composition and Analysis, 19(1):88-94. DOI: 10.1016/j.jfca.2004.11.006.

Dias, J.A.; Freire, P.; Freitas, C.; Klein, C.; Silva, P. (2011) - The importance of estuarine and coastal morphodynamics in littoral management. Journal of Integrated Coastal Zone Management, 11(3):271-272. DOI: 10.5894/rgci304.

Ferreira, J.G.; Andersen, J.H.; Borja, A.; Bricker, S.B.; Camp, J; Silva, M.C.; Garcés, E.; Heiskanen, A.S.; Humborg, C.; Ignatiades, L.; Lancelot, C.; Menesguen, A.; Tett, P.; Hoepffnerm, N.; Claussen, U. (2011) - Overview of eutrophication indicators to assess environmental status within the European Marine Strategy Framework Directive. Estuarine, Coastal and Shelf Science, 93(2):117-131. DOI: 10.1016/ j.ecss.2011.03.014.

Ferreira, J.G.; Bricker, S.B.; Simas, T.C. (2007) - Application and sensitivity testing of an eutrophication assessment method on coastal systems in the United States and European Union. Journal of Environmental Management, 82(4):433-445. DOI: 10.1016/ j.jenvman.2006.01.003.

Ferreira, J.G.; Wolff, W.J.; Simas, T.C.; Bricker, S.B. (2005) Does biodiversity of estuarine phytoplankton depend on hydrology?. Ecological Modelling, 187(4):513-523. DOI: 10.1016/j.ecolmodel .2005.03.013.

GEOHAB (2006) - Global Ecology and Oceanography of Harmful Algal Blooms. HAB in Eutrophic Systems. P. Glibert (ed.). IOC and SCOR, Paris and Baltimore, 74p. Available on-line at http://www.jodc.go.jp/info/ioc_doc/Other/FINAL_GEOHAB_Eutro_cor rected.pdf

Glibert, P.M.; Magnien, R.; Lomas, M.W.; Alexander, J.; Fan, C.; Haramoto, E.; Trice, M.; Kana, T.M. (2001) - Harmful algal blooms in the Chesapeake and Coastal Bays of Maryland, USA: Comparison of 1997, 1998, and 1999 events. Estuaries, 24(6):875-883. DOI: $10.2307 / 1353178$.

Glibert, P.M.; Seitzinger, S.; Heil, C.A.; Burkholder, J.M.; Parrow, M.W.; Codispoti, L.A.; Kelly, V. (2005) - The role of eutrophication in the global proliferation of harmful algal blooms. Oceanography, 18(2):198-209. DOI: 10.5670/oceanog. 2005.54 .

Grasshoff, K.; Ehrhardt, M.; Kremling, K. (1983) - Methods of seawater analysis, 2nd edn. VerlagChemie, Weinheim, Germany. ISBN: 3527259988.

Hallegraeff, G.M.; Anderson, D.M.; Cembella, A.D. (2003) Manual on harmful marine microalgae. Monographs on Oceanographic Methodology, 11. UNESCO Publishing: Paris, 793 pp. ISBN: 9231038710.
Helguera, Y.; Díaz-Asencio, L.; Fernández-Garcés, R.; GómezBatista, M.; Guillén, A.; Díaz-Asencio, M.; Armenteros, M. (2011) - Distribution patterns of macrofaunalpolychaete assemblages in a polluted semi-enclosed bay: Cienfuegos, Caribbean Sea. Marine Biology Research, 7(8):757-768. DOI: 10.1080/17451000.2011.569552.

Kudela, R.M.; Gobler, C.J. (2012) - Harmful dinoflagellate blooms caused by Cochlodinium sp.: Global expansion and ecological strategies facilitating bloom formation. Harmful Algae,14:7186. DOI: 10.1016/j.hal.2011.10.015.

Loza, S.; Moreira, A.; Comas, A.; Sánchez, M.; Carmenate, M.; Álamo, B.; Dobal, V.; Montalvo, J.; García, I.; Lorenzo, S.; Arriaza, L.; Hernández, M.; Montesinos, D.; Gutierréz, J.; M. Alcolado, P. (2013) - A Phaeocystis bloom in Cuban Archipelago. Harmful Algae News (ISSN: 0020-7918), 47:2021, UNESCO, Paris, France. Available on-line at https://www.researchgate.net/publication/237080347_A_Phaeocystis_bl oom_in_the_Cuban_Archipelago

Millero, F.J. (2006) - Chemical Oceanography, 3rd ed., 496p., CRC Press, Boca Raton, FL, U.S.A. ISBN: 978-0849322808.

Moreira, A.; Armenteros, M.; Gómez, M.; León, A.R.; Cabrera, R.; Castellanos, M.E.; Muñoz, A.; Suárez, A.M. (2006) - Variation of macroalgae biomass in Cienfuegos Bay, Cuba. Revista de Investigaciones Marinas. (ISSN: 1991-6089), 27(1):3-12, Centro de Investigaciones Marinas, Universidad de La Habana, Habana, Cuba. Available on-line at http://www.cim.uh.cu/rim/OldSite/ 2006/1.html.

Moreira, A., Seisdedo, M.; Leal, S.; Comas, A.; Delgado, G.; Regadera, R.; Alonso, C.; Muñoz, A.; Abatte, M. (2007) Composición y abundancia del fitoplancton de la bahía de Cienfuegos, Cuba. Revista de Investigaciones Marinas (ISSN: 1991-6089), 28(2):97-109, Centro de Investigaciones Marinas, Universidad de La Habana, Habana, Cuba. Available on-line at http://www.cim.uh.cu/rim/pdf/2007/2/2007-097.pdf.

Muñoz-Caravaca, A.; Doulliet, P.; Díaz-García, O.; Fichez, R.; Herrera, R.H.; Alcántara-Carrió, J.; García-Rodriguez, A. (2012) - Flushing time in the Cienfuegos Bay. Natural Resource Modeling, 25(3):434-455. DOI: 10.1111/j.1939-7445. 2012.00126.x.

NOAA (1985) - National estuarine inventory: Data atlas, vol.1: Physical and hydrologic characteristics. 103p., National Oceanic and Atmospheric Administration (NOAA), Strategic Assessment Branch, Ocean Assessments Division, Rockville, MD, U.S.A.

Reyes, T. (2008) - Niveles de eutrofización en las bahías de La Habana, Mariel, Matanzas, Cárdenas y Puerto Padre, Cuba. Dissertation of Bachelor, Universidad de La Habana, La Habana, Cuba. Unpublished.

Seisdedo, M.; Muñoz, A. (2005) - Efecto de las precipitaciones en la calidad de las aguas de la bahía de Cienfuegos. Revista Cubana de Meteorología (ISSN: 0864-151X), 12(2):64-67, Habana, Cuba.

Seisdedo, M.; Arencibia, G. (2010) - Estimación de carga contaminante de nutrientes en la bahía de Cienfuegos. Transporte, Desarrollo y Medio Ambiente (ISSN: 0864-151X), 30(64):33-37, La Habana, Cuba.

Smayda, T.J. (1997) - Harmful algal blooms: Their ecophysiology and general relevance to phytoplankton blooms in the sea. Limnology and Oceanography, $42(5$ pt 2): 1137-1153. DOI: 10.4319/1o.1997.42.5_part_2.1137

Tomas, C. R. (1997) - Identifying Marine Phytoplankton. 858p., Academic Press, San Diego, CA, U.S.A. ISBN:9780126930184. 
Troccoli, G.L.; Herrera-Silveira, J.A.; Comín, F.A. (2004) Structural variations of phytoplankton in the coastal seas of Yucatan, Mexico. Hydrobiologia, 519(1-3):85-102. DOI: 10.1023/B:HYDR.0000026487.78497.b6.

UNEP (1988) - Standard chemical methods for marine environmental monitoring 50p., United Nations Environment Programme (UNEP), Nairobi, Kenya.

Utermöhl, H. (1958) - Zur Vervollkommnung der quantitativen Phytoplankton-Methodik. Mitt. Int. Verhandlungen der Internationalen Vereinigung fur Theoretische und Angewandte
Limnologie, 9:1-38. Available on-line at http://www.schweizerbart. de/pubs/series/verhandlungen-ivl.167.html

Xiao, Y.; Ferreira, J.G.; Bricker, S.B.; Nunes, J.P.; Zhu, M.; Zhang, X. (2007) - Trophic assessment in Chinese coastal systems Review of methodologies and application to the Changjiang (Yangtze) estuary and Jiaozhou Bay. Estuaries and Coasts, 30(6):1-18. DOI: 10.1007/BF02841384

Zar, J. (2009) - Biostatistical analysis. 5th ed., 960p., Prentice Hall, Englewood Cliffs, NJ, U.S.A. ISBN: 978-0131008465.

The article

"Spatial and temporal distribution of phytoplankton as indicator of eutrophication status in the Cienfuegos Bay, Cuba", by Moreira et al. (2014), contains supporting information online at http://www.aprh.pt/rgci/pdf/rgci-506 Moreira_Supporting-Information.pdf 